\title{
Spontaneous right-sided ureterocolic fistula: a rare complication of colonic diverticular disease
}

\author{
Muhammad Qutayba Almerie, ${ }^{1}$ Adam Culverwell, ${ }^{2}$ Jonathan Gill, ${ }^{3}$ \\ Jonathan David Harrison ${ }^{1}$
}

'Departments of General Surgery, Harrogate District Hospital, Harrogate, UK ${ }^{2}$ Department of Radiology, Harrogate District Hospital Harrogate, UK

${ }^{3}$ Department of Urology, Harrogate District Hospital Harrogate, UK

\section{Correspondence to} Muhammad Qutayba Almerie, qalmerie@doctors.org.uk

Accepted 18 June 2015
CrossMark

To cite: Almerie MQ, Culverwell $A$, Gill J, et al. BMJ Case Rep Published online: [please include Day Month Year] doi:10.1136/ bcr-2015-211282

\section{DESCRIPTION}

Fistulae can result from diverticulitis-associated abscesses perforating into surrounding structures. Diverticular ureterocolic fistulae are rare, with only nine previous cases reported. ${ }^{1}$ They are usually related to previous operations and affect the left ureter due to its proximity to the sigmoid colon. ${ }^{2}$ In the absence of a non-functioning infected kidney, it is recommended to resect the diseased colon with no manipulation of the urinary system (eg, nephroureterectomy). ${ }^{2}$ Our case is the first to report a spontaneous right ureterocolic fistula secondary to diverticular disease in a patient with no previous abdominal operations.

A 68-year-old man presented with chronic lower abdominal discomfort associated with weight loss, erratic bowel habit and urinary symptoms including pneumaturia and recurrent urinary tract infections.
CT of the abdomen and pelvis showed an inflammatory diverticular mass of the sigmoid colon (figure 1) with complex fistulation to the right ureter (figure 2). Bilateral retrograde pyelograms revealed extravasation of contrast indicating the site of fistulation (figure 2).

Laparoscopic-converted-to-open anterior resection of the sigmoid mass with colorectal anastomosis and diverting loop ileostomy was performed. Bilateral ureteric stents were inserted at the start of the procedure. Intraoperatively, a large pelvic mass with extensively adherent small bowel was found. The challenging dissection of the mass was facilitated by palpating the stents to avoid injury to the ureters. The fistula was transected during the dissection and no urine leakage was observed. The ureteric stents were left for 8 weeks to prevent urine leakage and promote spontaneous closure of the fistula.
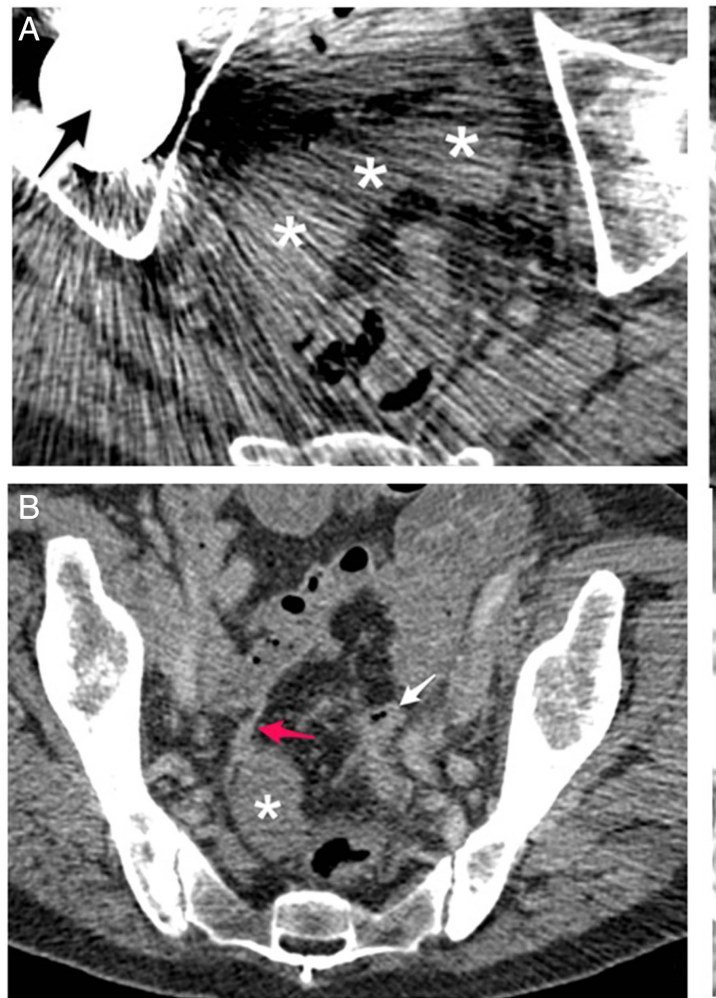

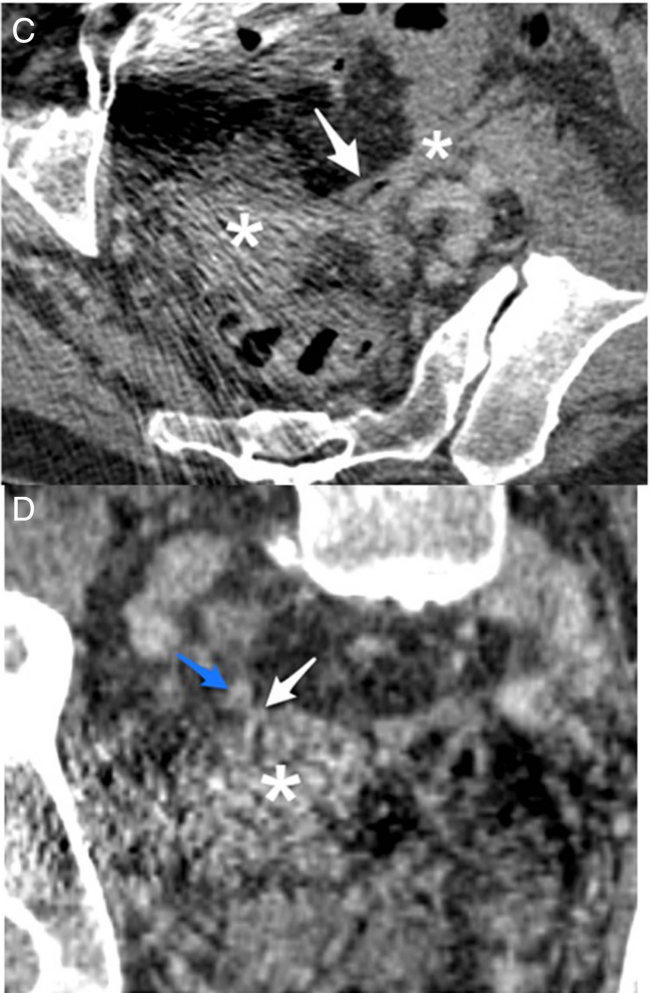

Figure 1 Series of images from a preoperative CT scan of the abdomen and pelvis. CT images are heavily distorted by the artefact from the metallic hip prosthesis (black arrow). On axial slices $(A-C)$ a thickened and inflamed sigmoid colon $\left(^{*}\right)$ is seen containing diverticular disease surrounded by several complex fistulae. Multiple fistula tracks are seen (white arrows); (B) shows enhancing air filled fistula track between proximal and distal sigmoid colon, (C) red arrow shows fistula track heading towards ureter (red arrow) and coronal CT reformat (D) shows fistula track meeting the ureter (blue arrow). 
Figure 2 Series of images from a preoperative imaging of the ureter. On axial $C T$ images, air is seen within the right renal collecting system $(A)$ and right ureter (B). Air is not seen on the left. Retrograde ureterography (C) shows leak of contrast from the distal ureter into the sigmoid colon (red arrow).
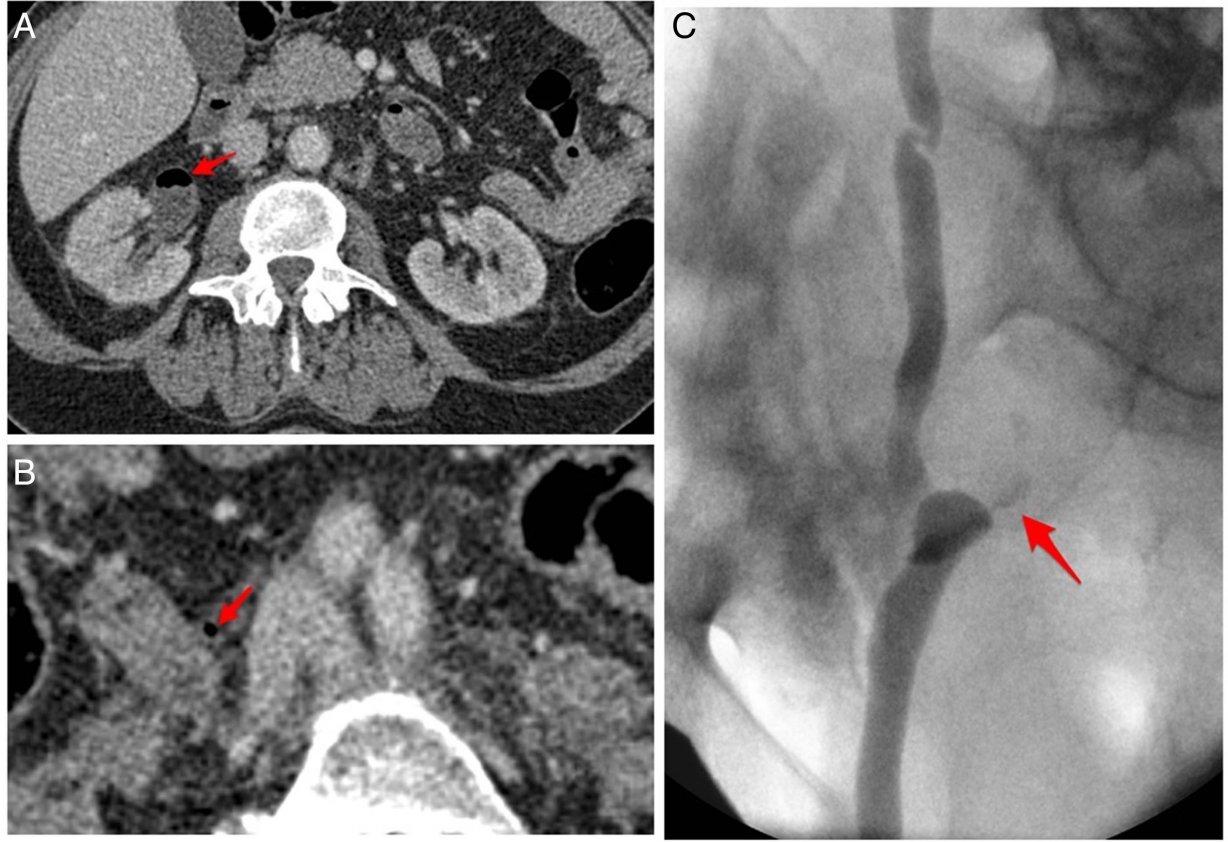

Contributors MQA conceptualised the case, wrote draft manuscript. AC provided images and captions, reviewed manuscript. JG conceptualised the case, reviewed manuscript. JDH conceptualised the case, reviewed manuscript.

Competing interests None declared.

Patient consent Obtained.

Provenance and peer review Not commissioned; externally peer reviewed. rare, and present with urinary symptoms and lower abdominal pain.

- CT scans and retrograde pyelograms are important investigations to confirm the diagnosis and delineate the anatomy.

- Surgical resection of the diseased colonic segment can be very challenging, and ureteric stents help avoid injury to the ureters intraoperatively.

\section{REFERENCES}

1 Pai A, Coralic J, Park JJ, et al. Spontaneous ureterocolic fistula secondary to diverticulitis: report of a case and review of literature. Int I Colorectal Dis 2014;29:417-18

2 Iwamoto $Y$, Kato M. A case with fistula formation between a perinephric retroperitoneal abscess, a ureter and descending colon: successful outcome after conservative management. Can Urol Assoc J 2014;8:E644-6.

Copyright 2015 BMJ Publishing Group. All rights reserved. For permission to reuse any of this content visit http://group.bmj.com/group/rights-licensing/permissions.

BMJ Case Report Fellows may re-use this article for personal use and teaching without any further permission.

Become a Fellow of BMJ Case Reports today and you can:

- Submit as many cases as you like

- Enjoy fast sympathetic peer review and rapid publication of accepted articles

- Access all the published articles

- Re-use any of the published material for personal use and teaching without further permission

For information on Institutional Fellowships contact consortiasales@bmjgroup.com

Visit casereports.bmj.com for more articles like this and to become a Fellow 